\title{
MANAGEMENT OF IRON DEFICIENCY STRESS IN KIWIFRUIT TREES (ACTINIADIA DELICIOSA) BY SOIL INJECTION
}

\author{
SHIRDEL SHAHMIRI, F. ${ }^{1}-$ EBADI, A. ${ }^{2 *}-$ SAMAR, S. M. ${ }^{3}-$ KHALIGHI, A. ${ }^{1}-$ ChERATI, A. ${ }^{4}$ \\ ${ }^{I}$ Department of Horticulture, Science and Research Branch, Islamic Azad University, Tehran, Iran \\ ${ }^{2}$ Department of Horticulture, Faculty of Agricultural Science and Natural Resources, \\ University of Tehran, Karaj, Iran \\ ${ }^{3}$ Soil and Water Research Institute, Tehran, Iran \\ ${ }^{4}$ Agricultural and Natural Research Center of Mazandran, Sari, Iran \\ *Corresponding author \\ e-mail:aebadi@ut.ac.ir \\ (Received 24 $4^{\text {th }}$ Feb 2017; accepted 25 $5^{\text {th }}$ Jul 2017)
}

\begin{abstract}
A factorial experiment using the randomized complete block design was conducted in 2013-2014 to study the effects of methods of controlling iron deficiency stress, and the chlorosis resulting from it, on the qualitative and quantitative characters of kiwi fruits. The factors included three levels of iron sulfate, sulfuric acid and organic matter in four replications. Results showed that the treatments had a significant effect on SPAD readings, maximum leaf iron content, the largest proline content, vitamin $\mathrm{C}$ and crop yield in both years. The treatments did not significantly influence the TSS/TA index in the two years. In all, results indicate that injection of two kilograms of iron sulfate together with half a liter of sulfuric acid and four kilograms of organic matter can be a suitable replacement for iron chelates in correcting iron chlorosis, and in increasing the qualitative and quantitative yield of kiwi trees for a period of at least two years.
\end{abstract}

Keywords: chelate, chlorosis, ferrous sulfate, sulfuric acid, organic matter

\section{Introduction}

Kiwi (Actinida deliciosa) enjoys relative advantages due to its high crop yield per hectare, its nutritional and medicinal values of its fruits and desirable postharvest storage life. Kiwi trees need suitable weather conditions and fertile soils. High soil lime content is one of the factors that threaten kiwi orchards. The high sensitivity of kiwi trees to high $\mathrm{pH}$ values, and to iron deficiency, causes chlorosis, loss of vigor, and reduced crop yield and fruit quality in kiwi orchards, especially in those with heavy- textured soils. Iron $(\mathrm{Fe})$ is an important micronutrient that plays crucial roles in plant growth, development, and reproduction (Vigani et al., 2013). Iron chelates such as Fe-EDDHA are used to quickly correct iron chlorosis in plants, but they are expensive and, besides that, must be applied every year (Pestana et al., 2003). Local placement of mineral iron salts together with organic matter (deep placement) is an effective method of controlling iron chlorosis, and improves fruit quality too, but it is labor-intensive and costly. Iron chlorosis symptoms in pear orchards can be corrected by adding acids to a limited volume of soil for neutralizing calcium carbonate (Kalbasi, 1986). Several experiments have shown the effectiveness of the method of injecting fertilizers into the soil as either solutions or suspensions. In one of 
them, iron (II) phosphate fertilizer was injected into the soil around mature kiwi trees in four places at the depth of 25-30 centimeters, into the soil of potted kiwi trees, and into the soil around one-year-old kiwi saplings. Results indicated that injection of the iron fertilizer Vivianite could be a suitable replacement for iron chelates in correcting chlorosis and in improving kiwi fruit quality (Rombola et al., 2003). Reducing the $\mathrm{pH}$ of the injected fertilizer can also be effective in increasing iron solubility. Solubility of iron containing minerals increases 1000- fold for every one-unit decrease in $\mathrm{pH}$ (Samar et al., 2011). Adding acidic materials to mineral fertilizers will result in a longer duration of iron solubility, and will thus increase iron absorption by roots (Havlin et al., 2005). Some species, such as Arabidopsis thaliana, produce phenolic compounds (Schmidt et al., 2014) while other species, including cucumber and melon, produce flavin compounds (RodríguezCelma et al., 2013). Although the function of flavin compounds in plant Fe deficiency is not well defined, they may function in reduction or complexation of extracellular Fe to facilitate Fe acquisition (Sisó-Terraza et al., 2016). In our experiment, the effectiveness of injecting iron sulfate fertilizer into the soil with a Biolift machine, and the probability of increasing its efficiency by adding acids and organic matter, in correcting chlorosis and improving the qualitative and quantitative characters of kiwi fruit were studied.

\section{Materials and Methods}

Mazandaran Province is considered one of the suitable places for growing kiwi trees and for producing kiwi fruit in Iran. This experiment was conducted in the central part of the Mazandaran with the latitude of $36^{\circ} 28^{\prime}$ north, longitude of $52^{\circ} 53^{\prime}$ east, altitude of 51.2 meters, and average annual temperature and rainfall of $16.7{ }^{\circ} \mathrm{C}$ and 725 millimeters, respectively, in 2013-2014. Physical and chemical characteristics of soil described in Table 1. The experiment was conducted in the factorial form using the randomized complete block design ( 28 treatments in four replications on 112 trees). The treatments included three levels of iron sulfate application $\left(0,1\right.$, and $2 \mathrm{~kg}$ per tree represented by $\mathrm{Fe}_{1}, \mathrm{Fe}_{2}$ and $\mathrm{Fe}_{3}$, respectively), three levels of sulfuric acid $\left(0,0.5\right.$, and 1 liter per tree represented by $\mathrm{AC}_{1}$, $\mathrm{AC}_{2}$ and $\mathrm{AC}_{3}$, respectively), and three levels of organic matter $(0,2$, and $4 \mathrm{~kg}$ of organic matter per tree represented by $\mathrm{OM}_{1}, \mathrm{OM}_{2}$ and $\mathrm{OM}_{3}$ ). In an additional treatment (other than those usually performed), the iron chelate treatment was employed as an effective fertilizer for correcting iron deficiency and for evaluating the effectiveness of the above-mentioned treatments. This treatment received 100 grams of the iron chelate Sequestrine (FeEDDHA) per tree in two stages. The first stage was in the first month of spring, and the second in the second month of spring and, in each stage, 50 grams of this iron chelate were dissolved in 20 liters of water and applied as fertigation at the base of each tree trunk in both years that the experiment was carried out. This treatment was considered as the sham treatment, and the treatment that did not receive any fertilizer as the control treatment. We mixed the materials needed in each treatment with 20 liters of water, turned the mixture into a suspension, and then injected the suspension into the soil with a Biolift machine at four points in the area shaded by each tree at the depth of 40-50 centimeters. These four points were at a distance of 75 centimeters from the tree trunk and the injections were carried out in the early part of the first month of spring in 2013. The force and pressure applied by the 
machine at each injection point spread the fertilizer combination in an area of about 0.12 square meters. With 20 liters of the suspension injected at four points around each tree (five liters per point), the volume of soil around each tree that was impregnated with the suspended materials was 0.2 cubic meter out of the total of 0.7 cubic meter. In other words, close to 30 percent of the volume of the soil around each tree was affected by the applied materials. The powdery type of iron sulfate was used, the sulfuric acid was of the commercial type with a concentration of 98 percent, and the organic matter was decomposed cow manure. To prepare the suspensions, the quantity of the organic matter specified by the levels used in the experiment was first mixed with 20 liters of water and the acid was then added. Twenty-four hours later, the calculated amount of iron sulfate for each treatment was poured into the mixture. We passed the prepared suspension through a filter and injected the filtrate into the soil using a fertilizer injection machine. This machine, with the trade name of MTM, had a compressor with a gasoline motor to produce pressurized air at the rate of 1260 liters per minute at the pressure of 9-11 bars, and had a nozzle with the maximum diameter of three millimeters for injection. At entrance into the soil, the compressed air created a network of small and large air channels that reduced soil compaction and, hence, improved soil aeration and infiltrability (for easier injection of the suspensions). After carrying out the treatments, other maintenance operations such as irrigation and pest and weed control were performed as are customary in the region.

Table 1. Physical and chemical characteristics of soil

\begin{tabular}{c|c|c|c|c|c|c|c|c|c|c|c}
\hline $\begin{array}{c}\text { Soil } \\
\text { texture }\end{array}$ & Zn & Mn & Mg & Fe & $\mathbf{P}$ & $\mathbf{K}$ & $\begin{array}{c}\text { Total } \\
\mathbf{N} \\
(\boldsymbol{\%})\end{array}$ & $\begin{array}{c}\text { T.N.V } \\
(\boldsymbol{\%})\end{array}$ & $\mathbf{p H}$ & $\begin{array}{c}\text { EC } \\
(\mathbf{d . S} / \mathbf{m})\end{array}$ & $\begin{array}{c}\mathbf{d e p t} \\
(\mathbf{c m})\end{array}$ \\
\hline \multicolumn{8}{c}{ p.p.m } \\
\hline L & 1.82 & 5.44 & 612 & 9 & 56 & 347 & 0.11 & 8.75 & 7.7 & 0.42 & $0-30$ \\
L & - & - & - & - & 52 & 307 & 0.1 & 10.5 & 7.8 & 0.4 & $30-60$ \\
\hline
\end{tabular}

The studied characters were as follows: SPAD reading with a SPAD-502 chlorophyll meter, leaf iron content with an atomic absorption machine, proline content by drawing the standard curve at the wavelength of 520 nanometers (the method introduced by Bates, 1973), and the proline concentration measured in milligrams per gram of fresh leaf. The ratio of sugar to acid or TSS/TA was calculated (the TSS was measured using a refractometer and TA, or titratable acidity, by titration with $0.1 \mathrm{~N}$ sodium hydroxide), and vitamin $\mathrm{C}$ content was measured by using the 2,6-dichloroindophenol titrimetric method. We used MSTATC to analyze the data and Duncan's test to compare the means.

\section{Results and Discussion}

\section{Chlorophyll assay (SPAD reading)}

The individual effects of iron sulfate, sulfuric acid, and organic matter on the chlorophyll index that were measured in the early part of the last month of summer in both years were statistically significant at the $1 \%$ probability level. The effects of the interactions between the treatments of applying iron sulfate, sulfuric acid, and organic 
matter on the chlorophyll content of the leaves were significant at the $1 \%$ probability level, as compared to effects of iron chelate application (Table 2). Leaf chlorophyll content in the $\mathrm{Fe}_{3} \mathrm{AC}_{3} \mathrm{OM}_{3}$ treatment increased by $39.9 \%$ compared to the chelate treatment, and that of the chelate treatment by $18.8 \%$ compared to the control $\left(\mathrm{Fe}_{1} \mathrm{AC}_{1} \mathrm{OM}_{1}\right)$ (Table 5). Conducted studies on the sensitivity of kiwi varieties to iron deficiency have shown that iron deficiency reduces leaf chlorophyll content in all kiwi varieties (Rombola et al., 2002). Injection of a solution containing Fe-EDDHA and organic matter into the soil in a peach orchard significantly increased leaf chlorophyll index (SPAD reading) (Tsipouridis et al., 2006). Injection of iron (II) phosphate into olive trees improved yield and leaf color stability index for more than two years (Rosado et al., 2002). Iron deficiency was followed by leaf yellowing, by reduced vegetative growth and leaf surface area, by diminished flowering and fruit set and, hence, by lowered crop yield and quality (Alvarez-Fernandez et al., 2003). These results conform to ours because we found that there were significant differences between leaf chlorophyll concentrations in the control, iron chelate, and iron sulfate + sulfuric acid+ organic matter treatments. Since one of the most important roles played by iron is in enzymatic activities, and because iron forms a part of the structure of enzymes (and activates them), it has an essential role in the metabolism of nucleic acids and proteins because nucleic acids contain considerable amounts of iron and other heavy metals. Accumulation of nitrates, amino acids, and amides, and reduction of proteins, under conditions of iron deficiency are signs of the effects of iron in protein synthesis; and these conditions return to normal when required iron is provided. Among various proteins, chlorophyll is strongly affected by iron deficiency leading to lack of development, and reduced quantities, of leaf chlorophyll, less photosynthesis, and diminished vegetative growth. Increased availability of iron results in more chlorophyll production and in less yellowing and chlorosis. Following that, photosynthesis increases, more raw xylem sap is used, more water and minerals are absorbed from the soil, more phloem sap is produced and more nutrients will be available, leading to increased vegetative growth, especially longitudinal growth of branches and greater leaf surface area (Havlin et al., 2005).

Table 2. Analysis of variance of SPAD reading, leaf Fe concentration, proline, yield, fruit TSS/TA and vitamin c in 2013 year

\begin{tabular}{|c|c|c|c|c|c|c|c|}
\hline \multicolumn{6}{|c|}{ Mean square } & \multirow[b]{2}{*}{ DF } & \multirow[b]{2}{*}{ Source } \\
\hline Vitamin c & TSS/TA & Yield & Proline & Leaf $\mathrm{Fe}$ & $\begin{array}{c}\text { SPAD } \\
\text { reading }\end{array}$ & & \\
\hline $510.16^{*}$ & $7.631^{*}$ & $334.02^{*}$ & $0.0001^{*}$ & $1524.75^{*}$ & $94.3^{*}$ & 3 & Replications \\
\hline $138.12^{\mathrm{ns}}$ & $2.693^{\mathrm{ns}}$ & $775.88^{* *}$ & $0.001^{* *}$ & $1711.29^{* *}$ & $206.2^{* *}$ & 27 & Treatment \\
\hline 94.19 & 2.341 & 142.99 & 0.0001 & 671.93 & 29.03 & 81 & error \\
\hline 16.58 & 14.93 & 40.6 & 23.74 & 13.28 & 14.18 & & $(\%) \mathrm{CV}$ \\
\hline
\end{tabular}

ns and *,*, respectively, according to F-test non-significant and significant at 5 and 1 percent 


\section{Leaf iron concentration}

Individual effects of applying iron sulfate and sulfuric acid on iron leaf concentration were statistically significant in both years at the $5 \%$ probability level. The interaction of the effects of applying a combination of iron sulfate, sulfuric acid, and organic matter were also significant at the $1 \%$ probability level (Tables 2, 3). Comparison of the iron chelate and the iron sulfate + sulfuric acid+ organic matter treatments also indicated significant differences in leaf iron concentrations at the $1 \%$ probability level (Tables 2 and 3). In 2013, the treatment $\mathrm{Fe}_{2} \mathrm{AC}_{2} \mathrm{OM}_{1}$ yielded the highest leaf iron concentration that was 19.9 percent more than the iron chelate treatment and 28.5 percent more than the control, while leaf iron concentration in the iron chelate treatment was 10.7 percent higher compared to the control. In 2014, the $\mathrm{Fe}_{2} \mathrm{AC}_{3} \mathrm{OM}_{3}$ treatment showed the highest leaf iron concentration that was 4.9 percent more than the superior treatment of the first year and 23.5 and 34.4 percent higher compared to those of the iron chelate and the control treatments, respectively (Table 4). Comparisons indicated that leaf chlorosis of untreated trees (the control) worsened in the second year. Crane et al. (2007) showed that leaf iron content in sulfuric acid treatments (or in treatments of citric acid plus iron sulfate) resulted in the highest leaf iron content compared to the iron sulfate, acid, or iron chelate treatments. Presence of organic matter in soil is effective in the reduction reaction of iron because decomposing organic matter transfer electrons to trivalent iron and reduce it and, thus, increase iron concentration in soil solution. Organic molecules form organometallic complexes with iron or with some of the other cations and these complexes increase the capability of absorbing elements. Moreover, the beneficial effects of adding organic matter together with mineral iron compounds sustain the capability of absorbing the iron present in mineral compounds (i. e., prevent or delay precipitation) and thus make it possible for plants to absorb more of this element (Samar et al., 2011).

Table 3. Analysis of variance of SPAD reading, leaf Fe concentration, proline, yield, fruit TSS/TA and vitamin $c$ in year 2014

\begin{tabular}{|c|c|c|c|c|c|c|c|}
\hline \multicolumn{6}{|c|}{ Mean square } & \multirow[b]{2}{*}{ DF } & \multirow[b]{2}{*}{ Source } \\
\hline Vitamin C & TSS/TA & Yield & Proline & Leaf Fe & $\begin{array}{l}\text { SPAD } \\
\text { reading }\end{array}$ & & \\
\hline $158.10^{*}$ & $1.11^{*}$ & $261.06^{\mathrm{ns}}$ & $0.0001^{\mathrm{ns}}$ & $617.94^{\mathrm{ns}}$ & $65.6^{\mathrm{ns}}$ & 3 & Replications \\
\hline $88.50^{*}$ & $1.80^{\mathrm{ns}}$ & $1177.98^{* *}$ & $0.001^{* *}$ & $2114.87^{* *}$ & $265.4^{* *}$ & 27 & Treatment \\
\hline 47.35 & 2.44 & 113.25 & 0.0001 & 399.90 & 27.1 & 81 & error \\
\hline 11.36 & 14.42 & 33.44 & 24.77 & 9.89 & 13.95 & & $(\%) \mathrm{CV}$ \\
\hline
\end{tabular}

ns and *, **, respectively, according to F-test non-significant and significant at 5 and 1 percent

\section{Proline}

The individual effects of iron sulfate and organic matter on leaf proline content were statistically significant at the $5 \%$ and $1 \%$ probability levels, respectively. Effects of the 
interactions of applying iron + acid + organic matter on leaf proline content were very significant at the $1 \%$ probability level (Table 2). In 2013, the highest leaf proline content (0.104 milligram per gram of fresh leaf) was that of the $\mathrm{Fe}_{3} \mathrm{AC}_{3} \mathrm{OM}_{3}$ treatment, which was 76.9 and 35.8 percent more than the control and the iron chelate treatments, respectively. In 2014, the $\mathrm{Fe}_{2} \mathrm{AC}_{3} \mathrm{OM}_{3}$ treatment had the maximum leaf proline content, which was 61.8 and 25 percent higher compared to the control and the iron chelate treatments, respectively (Table 4).

Table 4. Effect of application of ferrous sulfate, sulfuric acid and organic matter on SPAD reading, iron leaf concentration, leaf proline content during 2013-2014

\begin{tabular}{|c|c|c|c|c|c|c|c|c|}
\hline \multicolumn{2}{|c|}{$\begin{array}{l}\text { Proline } \\
\text { (mg/gr) }\end{array}$} & \multicolumn{2}{|c|}{$\begin{array}{c}\text { Leaf Iron } \\
\text { (micgr/gr) }\end{array}$} & \multicolumn{2}{|c|}{ (SPAD reading) } & \multicolumn{3}{|c|}{ Treatment } \\
\hline 2014 & 2013 & 2014 & 2013 & 2014 & 2013 & OM & Asid & $\mathbf{F e}$ \\
\hline $0.029 \mathrm{k}$ & $0.024 c$ & $162 \mathrm{k}$ & 168 e-f & $20.3 \mathrm{~m}$ & $24.4 \mathrm{~L}$ & $\mathrm{OM}_{1}$ & $\mathrm{AS}_{1}$ & $\mathrm{Fe}_{1}$ \\
\hline $0.03 \mathrm{k}$ & $0.029 \mathrm{bc}$ & $180 \mathrm{i}-\mathrm{k}$ & $181 \mathrm{~d}-\mathrm{f}$ & $22.71-\mathrm{m}$ & $26.6 \mathrm{k}-1$ & $\mathrm{OM}_{2}$ & $\mathrm{AS}_{1}$ & $\mathrm{Fe}_{1}$ \\
\hline $0.065 \mathrm{a}-\mathrm{f}$ & $0.065 \mathrm{a}-\mathrm{c}$ & $173 \mathrm{j}-\mathrm{k}$ & 175 e-f & $25.8 \mathrm{k}-\mathrm{m}$ & $30.8 \mathrm{~g}-1$ & $\mathrm{OM}_{3}$ & $\mathrm{AS}_{1}$ & $\mathrm{Fe}_{1}$ \\
\hline $0.059 \mathrm{a}-\mathrm{g}$ & $0.06 \mathrm{a}-\mathrm{c}$ & $190 \mathrm{f}-\mathrm{k}$ & $186 \mathrm{~b}-\mathrm{f}$ & $30.5 \mathrm{~h}-1$ & $30.3 \mathrm{~h}-1$ & $\mathrm{OM}_{1}$ & $\mathrm{AS}_{2}$ & $\mathrm{Fe}_{1}$ \\
\hline $0.068 \mathrm{a}-\mathrm{d}$ & $0.072 \mathrm{a}-\mathrm{c}$ & $199 \mathrm{e}-\mathrm{k}$ & $197 \mathrm{a}-\mathrm{f}$ & $28.9 \mathrm{i}-1$ & $29.1 \mathrm{i}-1$ & $\mathrm{OM}_{2}$ & $\mathrm{AS}_{2}$ & $\mathrm{Fe}_{1}$ \\
\hline $0.054 c-i$ & $0.065 \mathrm{a}-\mathrm{c}$ & $180 \mathrm{~h}-\mathrm{k}$ & $177 \mathrm{~d}-\mathrm{f}$ & $38.2 \mathrm{c}-\mathrm{h}$ & $39.4 \mathrm{~b}-\mathrm{g}$ & $\mathrm{OM}_{3}$ & $\mathrm{AS}_{2}$ & $\mathrm{Fe}_{1}$ \\
\hline $0.057 \mathrm{~b}-\mathrm{h}$ & $0.052 \mathrm{a}-\mathrm{c}$ & $188 \mathrm{f}-\mathrm{k}$ & 198 a-f & $26.7 \mathrm{j}-\mathrm{m}$ & $27.3 \mathrm{j}-1$ & $\mathrm{OM}_{1}$ & $\mathrm{AS}_{3}$ & $\mathrm{Fe}_{1}$ \\
\hline $0.042 \mathrm{~h}-\mathrm{k}$ & $0.046 \mathrm{bc}$ & $191 \mathrm{f}-\mathrm{k}$ & $185 b-f$ & $34.5 \mathrm{e}-\mathrm{j}$ & $35.5 \mathrm{e}-\mathrm{k}$ & $\mathrm{OM}_{2}$ & $\mathrm{AS}_{3}$ & $\mathrm{Fe}_{1}$ \\
\hline $0.049 \mathrm{f}-\mathrm{j}$ & $0.054 \mathrm{a}-\mathrm{c}$ & $206 c-j$ & 209 a-e & $36.2 \mathrm{~d}-\mathrm{i}$ & $35.4 \mathrm{e}-\mathrm{k}$ & $\mathrm{OM}_{3}$ & $\mathrm{AS}_{3}$ & $\mathrm{Fe}_{1}$ \\
\hline $0.053 \mathrm{~d}-\mathrm{j}$ & $0.058 \mathrm{a}-\mathrm{c}$ & 228 a-e & $224 a-c$ & $35.4 \mathrm{~d}-\mathrm{i}$ & $35.5 \mathrm{e}-\mathrm{k}$ & $\mathrm{OM}_{1}$ & $\mathrm{AS}_{1}$ & $\mathrm{Fe}_{2}$ \\
\hline $0.048 \mathrm{~g}-\mathrm{j}$ & $0.052 \mathrm{a}-\mathrm{c}$ & $177 \mathrm{i}-\mathrm{k}$ & $157 \mathrm{f}$ & $34.1 \mathrm{f}-\mathrm{k}$ & $36.9 \mathrm{~d}-\mathrm{i}$ & $\mathrm{OM}_{2}$ & $\mathrm{AS}_{1}$ & $\mathrm{Fe}_{2}$ \\
\hline 0.067 a-e & $0.073 \mathrm{a}-\mathrm{c}$ & $184 \mathrm{~g}-\mathrm{k}$ & 174 e-f & $31.6 \mathrm{~g}-\mathrm{k}$ & $33.8 \mathrm{f}-\mathrm{k}$ & $\mathrm{OM}_{3}$ & $\mathrm{AS}_{1}$ & $\mathrm{Fe}_{2}$ \\
\hline $0.037 \mathrm{i}-\mathrm{k}$ & $0.04 \mathrm{bc}$ & $243 a b$ & $235 \mathrm{a}$ & 42.5 a-f & $40.7 \mathrm{a}-\mathrm{f}$ & $\mathrm{OM}_{1}$ & $\mathrm{AS}_{2}$ & $\mathrm{Fe}_{2}$ \\
\hline $0.048 \mathrm{f}-\mathrm{j}$ & 0.049 bc & 235 a-d & $219 \mathrm{a}-\mathrm{d}$ & $45.6 \mathrm{a}-\mathrm{c}$ & 43.9a-e & $\mathrm{OM}_{2}$ & $\mathrm{AS}_{2}$ & $\mathrm{Fe}_{2}$ \\
\hline $0.051 \mathrm{e}-\mathrm{j}$ & $0.051 \mathrm{a}-\mathrm{c}$ & 196 e-j & $184 c-f$ & $49.1 \mathrm{a}$ & $46.7 \mathrm{a}-\mathrm{c}$ & $\mathrm{OM}_{3}$ & $\mathrm{AS}_{2}$ & $\mathrm{Fe}_{2}$ \\
\hline $0.037 \mathrm{Jk}$ & $0.035 \mathrm{bc}$ & $172 \mathrm{j}-\mathrm{k}$ & $158 \mathrm{f}$ & $43.1 \mathrm{a}-\mathrm{e}$ & $43.2 \mathrm{a}-\mathrm{e}$ & $\mathrm{OM}_{1}$ & $\mathrm{AS}_{3}$ & $\mathrm{Fe}_{2}$ \\
\hline $0.056 \mathrm{~b}-\mathrm{h}$ & $0.055 \mathrm{a}-\mathrm{c}$ & $220 \mathrm{a}-\mathrm{f}$ & 202 a-e & $45.9 \mathrm{a}-\mathrm{c}$ & $45.4 \mathrm{a}-\mathrm{d}$ & $\mathrm{OM}_{2}$ & $\mathrm{AS}_{3}$ & $\mathrm{Fe}_{2}$ \\
\hline $0.076 \mathrm{a}$ & $0.08 \mathrm{ab}$ & $247 \mathrm{a}$ & $234 \mathrm{a}$ & $43.3 \mathrm{a}-\mathrm{d}$ & $44.1 \mathrm{a}-\mathrm{e}$ & $\mathrm{OM}_{3}$ & $\mathrm{AS}_{3}$ & $\mathrm{Fe}_{2}$ \\
\hline $0.058 \mathrm{~b}-\mathrm{h}$ & $0.059 \mathrm{a}-\mathrm{c}$ & e-j198 & $190 \mathrm{~b}-\mathrm{f}$ & 36 d-i & $36 e-j$ & $\mathrm{OM}_{1}$ & $\mathrm{AS}_{1}$ & $\mathrm{Fe}_{3}$ \\
\hline $0.071 \mathrm{ab}$ & $0.081 \mathrm{ab}$ & $210 \mathrm{~b}-\mathrm{i}$ & 202 a-e & $35.1 \mathrm{~d}-\mathrm{j}$ & $35.2 \mathrm{e}-\mathrm{k}$ & $\mathrm{OM}_{2}$ & $\mathrm{AS}_{1}$ & $\mathrm{Fe}_{3}$ \\
\hline $0.056 \mathrm{~b}-\mathrm{i}$ & $0.059 \mathrm{a}-\mathrm{c}$ & $216 \mathrm{a}-\mathrm{g}$ & 206 b-f & 39.7 b-g & $38.4 \mathrm{c}-\mathrm{h}$ & $\mathrm{OM}_{3}$ & $\mathrm{AS}_{1}$ & $\mathrm{Fe}_{3}$ \\
\hline $0.070 \mathrm{a}-\mathrm{c}$ & $0.07 \mathrm{a}-\mathrm{c}$ & $213 b-h$ & 197 a-f & 43 a-e & $43.4 \mathrm{a}-\mathrm{e}$ & $\mathrm{OM}_{1}$ & $\mathrm{AS}_{2}$ & $\mathrm{Fe}_{3}$ \\
\hline $0.069 \mathrm{a}-\mathrm{d}$ & $0.073 \mathrm{a}-\mathrm{c}$ & $221 \mathrm{a}-\mathrm{f}$ & 202 a-e & 42.9 a-e & $47.1 \mathrm{a}-\mathrm{c}$ & $\mathrm{OM}_{2}$ & $\mathrm{AS}_{2}$ & $\mathrm{Fe}_{3}$ \\
\hline $0.055 \mathrm{~b}-\mathrm{i}$ & $0.06 \mathrm{a}-\mathrm{c}$ & $190 \mathrm{f}-\mathrm{k}$ & $187 \mathrm{~b}-\mathrm{f}$ & 48 a-b & $47.8 \mathrm{ab}$ & $\mathrm{OM}_{3}$ & $\mathrm{AS}_{2}$ & $\mathrm{Fe}_{3}$ \\
\hline $0.037 \mathrm{Jk}$ & $0.038 \mathrm{~b}-\mathrm{f}$ & $204 d-j$ & 199 a-f & $37.8 \mathrm{c}-\mathrm{h}$ & 39.8 b-g & $\mathrm{OM}_{1}$ & $\mathrm{AS}_{3}$ & $\mathrm{Fe}_{3}$ \\
\hline $0.027 \mathrm{~K}$ & $0.028 \mathrm{c}$ & 212 b-h & $193 \mathrm{a}-\mathrm{f}$ & $46.2 \mathrm{a}-\mathrm{c}$ & $47.1 \mathrm{a}-\mathrm{c}$ & $\mathrm{OM}_{2}$ & $\mathrm{AS}_{3}$ & $\mathrm{Fe}_{3}$ \\
\hline $0.068 \mathrm{a}-\mathrm{d}$ & $0.0104 \mathrm{a}$ & $239 a-c$ & $228 \mathrm{ab}$ & $51.1 \mathrm{a}$ & $49.2 \mathrm{a}$ & $\mathrm{OM}_{3}$ & $\mathrm{AS}_{3}$ & $\mathrm{Fe}_{3}$ \\
\hline $0.057 \mathrm{~b}-\mathrm{h}$ & $0.067 \mathrm{~d}-\mathrm{e}$ & $189 \mathrm{f}-\mathrm{k}$ & $188 \mathrm{~b}-\mathrm{g}$ & $31.6 \mathrm{~g}-\mathrm{k}$ & 30 h-1 & $(\mathrm{Fe}$ & Chel & ate) \\
\hline
\end{tabular}

$*$ values followed by same letters do not differ significantly at $0.05 \%$ significant level

$\mathrm{Fe}_{1}, \mathrm{Fe}_{2}$ and $\mathrm{Fe}_{3}$, respectively, 0,1 and $2 \mathrm{~kg}$ of ferrous sulfate, $\mathrm{AC}_{1}, \mathrm{AC}_{2}$ and $\mathrm{AC}_{3}$, respectively, 0, 5/0, and 1

$\mathrm{L}$ of sulfuric acid and $\mathrm{OM}_{1}, \mathrm{OM}_{2}$ and $\mathrm{OM}_{3}$, respectively, 0,2 and $4 \mathrm{~kg}$ organic matter per tree 
In general, proline accumulation declined in all treatments except for the control in the second year, after the treatments were performed. In a research on two species of the monocot plant Triglochin, the effects of providing food nutrients and salinity on growth, on quantities of absorbed elements and on proline content were studied. It was found that increases in the soil content of heavy metals such as iron, manganese, zinc, and copper, from the optimum to the usual content (which in the case of this experiment was excessive), raised the proline content of leaves and roots. This shows that plants respond to the stress of excessive content of heavy elements including iron (Karlsons et al., 2011). Biochemical studies of the effects of iron deficiency on leaves of macadamia trees indicated that nonprotein amino acids such as arginine and lysine, organic acids, and citric acid accumulated in chlorotic leaves (Gilfillan, 1967).

In an experimented that was conducted on safflower, it was concluded that, when plants were not under water stress, applying iron fertilizer to the soil resulted in the highest proline accumulation compared to foliar application (Fathi Amirkhiz et al., 2011). Research on tomatoes also showed that deficiency stress of micronutrients such as iron, zinc, copper, and manganese had significant effects on the contents of amino acids and amides, and that iron deficiency stress increased the contents of amides more than it did those of amino acids such as proline (Possingham, 1956). In a study on the effects of phosphorous fertilizer and foliar spray of iron chelates on protein and dissolved carbohydrate contents of wheat, it was found that, although proline content increased by applying phosphorous fertilizer at flowering, iron fertilizer application at stem elongation and flowering stages had no significant effects on proline content (Akbari et al., 2013).

Wong (2009) conducted a study on wheat and concluded that the effects of iron deficiency stress on leaf proline content were not significant, but that the effects of iron fertilizer application, especially when plants faced salinity and UV stress, somewhat increased wheat leaf proline content. Various reports indicate that plant protein content declines when iron is deficient, and since no relationship has been established between proline content and iron deficiency, proline cannot protect plants under conditions of iron deficiency (Wong, 2009). Based on the findings of various researchers, it has been proved that nutritional stresses, such as potassium, phosphorous, magnesium, chlorine, and copper deficiencies, are accompanied by proline accumulation, but that iron deficiency causes accumulation of amino acids like arginine, asparagines, histidine, lysine, and serine in plants (Rabe, 1999). Under environmental stresses, organic solutions with low molecular weights such as amino acids and sugars accumulate in plants. Increases in the concentrations of dissolved free sugars and proline (which are among the most important potential participants in osmotic regulation) under stress conditions have been reported repeatedly. In general, there are two major pathways of proline synthesis: the glutamate pathway in which cytoplasmic enzymes are involved, and the ornithine pathway in which mitochondrial enzymes take part. The glutamate pathway is of greater importance in plants, and it seems the main enzymes of this pathway respond positively to zinc and iron sprays (Delaney et al., 1993). In our experiment, iron deficiency stress did not significantly increase proline accumulation either, but application of iron fertilizer and organic matter increased proline synthesis in kiwi trees. 


\section{Fruit yield}

Individual and mutual effects of treatments significantly influenced fruit yield at one percent probability level in both years the experimented was conducted (Tables 2 and 3). Injection of two kilograms of iron sulfate, or 0.5 liter of sulfuric acid, or four kilograms of organic matter, increased fruit yield by 48 and 60.7 percent, by 30.8 and 33 percent, and by 49.3 and 49.1 percent compared to the control treatment in the first and second years, respectively. In comparison, as for the interactions of the effects of iron sulfate + sulfuric acid + organic matter in 2013, fruit yield was largest in the $\mathrm{Fe}_{3} \mathrm{AC}_{2} \mathrm{OM}_{3}$ treatment, 73 percent more than the iron chelate treatment or sham treatment and 80.1 percent compared to the control, and that of the iron chelate treatment 24.7 percent more compared to the control. In the second year of the experiment, although no new fertilizer treatments were considered for the studied trees, the treatments that had received suitable amounts of iron fertilizer in the previous year exhibited desirable fruit growth and development. The maximum fruit yield, like the previous year, belonged to the treatment of applying one kilogram of iron sulfate, 0.5 liter of sulfuric acid, and four kilograms of organic matter.

This was the $\mathrm{Fe}_{3} \mathrm{AC}_{2} \mathrm{OM}_{3}$ treatment with fruit yield of 79.9 percent higher than the iron chelate (or sham treatment) and 84.4 percent more than the control, while the fruit yield of the iron chelate treatment was 22.2 percent more than the control (Table 5). In research conducted by Iglesias et al. (2003), injection of iron (II) sulfate into calcareous soil effectively prevented iron chlorosis in pear trees. Chlorophyll levels in treated trees significantly differed from those of the control, but did not show significant differences with trees treated with iron chelate. Studies in the following years indicated that the extents of flowering and fruit set increased significantly compared to the control treatment, but were lower than were those of the chelate treatments. The mean four-year yield in trees treated with iron (II) sulfate did not significantly differ from that of trees treated with iron chelate but differed very significantly from that of the control. Rombola et al. (2003) conducted an experiment in which they injected iron (II) phosphate fertilizer into the soil at the depths of 25-30 centimeters at four points around mature kiwi trees and compared the effects with those of Fe-EDDHA solution. They found that injection of this fertilizer into the soil could be an effective replacement for iron chelate fertilizers in improving quantitative indices of kiwi. Faust (1989) stated that iron chlorosis mainly occurred in young leaves due to the immobility of iron in plant leaves, but that lower leaves were also affected by chlorosis and intangible reduction of chlorophyll levels happened in lower leaves too. This condition led to a reduction in the extent of photosynthesis and in the efficiency of leaf photosynthesis in all parts of the plants including old parts that did not exhibit chlorosis and, hence, efficiency, carbohydrate accumulation, flower induction and fertilization, and plant yield decreased due to the general decline in plant photosynthesis. Since cytochromes $b$ and $c$ (that contain iron) play an important role in the electron transfer of the respiration process, iron deficiency can disturb plant respiration and, as a result, disturb other plant physiological mechanisms leading to reduced growth, development, and yield. Considering the role iron plays in the reduction of nitrates in plants, and given that nitrates and ammonium are important sources of mineral nitrogen absorbed by higher plants, nitrates must be reduced to ammonium to enter into the structure of organic compounds. This process happens under the influence of various enzymes, and iron plays 
the major role in the activities of these enzymes (Rombola and Tagliavini, 2006). Since iron plays a role in the metabolism of organic acids and other biomolecules, its deficiency leads to a reduction in sugar content, especially a reduction in the content of reducing sugars, cofactors such as riboflavin, other vitamins, flavins, and mononucleotides. Any of these disturbances can cause disorders in the natural plant growth and development system and, hence, can reduce growth and development, fruit size, weight, and quality, and, eventually, can reduce yield.

Table 5. Effect of application of ferrous sulfate, sulfuric acid and organic matter on yield, fruit TSS/TA and vitamin C during 2013-2014

\begin{tabular}{|c|c|c|c|c|c|c|c|c|}
\hline \multicolumn{2}{|c|}{ Vitamin C (mg/100gr) } & \multicolumn{2}{|c|}{ Fruit TSS/TA (\%) } & \multicolumn{2}{|c|}{ Yield (kg) } & \multicolumn{3}{|c|}{ Treatment } \\
\hline 2014 & 2013 & 2014 & 2013 & 2014 & 2013 & OM & Asid & $\mathbf{F e}$ \\
\hline $52.6 \mathrm{de}$ & $54.13 \mathrm{a}-\mathrm{c}$ & $10.90 \mathrm{ab}$ & $11.32 \mathrm{ab}$ & $11.2 \mathrm{i}-\mathrm{k}$ & $12.7 \mathrm{ij}$ & $\mathrm{OM}_{1}$ & $\mathrm{AS}_{1}$ & $\mathrm{Fe}_{1}$ \\
\hline 60 a-e & $59.3 \mathrm{a}-\mathrm{c}$ & $10.01 \mathrm{ab}$ & $8.27 \mathrm{c}$ & $10.5 \mathrm{Jk}$ & $11.7 \mathrm{ij}$ & $\mathrm{OM}_{2}$ & $\mathrm{AS}_{1}$ & $\mathrm{Fe}_{1}$ \\
\hline $53.9 \mathrm{c}-\mathrm{e}$ & $53.83 \mathrm{a}-\mathrm{c}$ & $10.57 \mathrm{ab}$ & $9.63 \mathrm{bc}$ & $16.1 \mathrm{~g}-\mathrm{k}$ & $19 \mathrm{~h}-\mathrm{j}$ & $\mathrm{OM}_{3}$ & $\mathrm{AS}_{1}$ & $\mathrm{Fe}_{1}$ \\
\hline 54 c-e & $51.65 \mathrm{a}-\mathrm{c}$ & $10.90 \mathrm{ab}$ & $9.42 b c$ & $6.48 \mathrm{~K}$ & $7.5 \mathrm{j}$ & $\mathrm{OM}_{1}$ & $\mathrm{AS}_{2}$ & $\mathrm{Fe}_{1}$ \\
\hline $49.3 \mathrm{e}$ & $3.8 \mathrm{bc}$ & $9.99 \mathrm{ab}$ & $10.61 \mathrm{a}-\mathrm{c}$ & $17.5 \mathrm{~g}-\mathrm{k}$ & $18.8 \mathrm{~h}-\mathrm{j}$ & $\mathrm{OM}_{2}$ & $\mathrm{AS}_{2}$ & $\mathrm{Fe}_{1}$ \\
\hline $61.9 \mathrm{a}-\mathrm{d}$ & $15 \mathrm{ab}$ & $11.52 \mathrm{ab}$ & $.68 \mathrm{a}-\mathrm{c}$ & $31.2 \mathrm{e}-\mathrm{h}$ & $36.5 \mathrm{c}-\mathrm{g}$ & $\mathrm{OM}_{3}$ & $\mathrm{AS}_{2}$ & $\mathrm{Fe}_{1}$ \\
\hline $64.2 \mathrm{a}-\mathrm{d}$ & $.85 \mathrm{ab}$ & & $10.97 \mathrm{ab}$ & $16.9 \mathrm{~g}-\mathrm{k}$ & $17 \mathrm{~h}-\mathrm{j}$ & $\mathrm{OM}_{1}$ & $\mathrm{AS}_{3}$ & $\mathrm{Fe}_{1}$ \\
\hline 58.6 a-e & $56.08 \mathrm{a}-\mathrm{c}$ & $11.88 \mathrm{ab}$ & $9.55 \mathrm{bc}$ & $17 \mathrm{~g}-\mathrm{k}$ & $18.8 \mathrm{~h}-\mathrm{j}$ & $\mathrm{OM}_{2}$ & $\mathrm{AS}_{3}$ & $\mathrm{Fe}_{1}$ \\
\hline 59.8 a-e & $58.83 \mathrm{a}-\mathrm{c}$ & $10.32 \mathrm{ab}$ & $9.80 \mathrm{bc}$ & $29 \mathrm{e}-\mathrm{i}$ & $35.1 \mathrm{c}-\mathrm{g}$ & $\mathrm{OM}_{3}$ & $\mathrm{AS}_{3}$ & $\mathrm{Fe}_{1}$ \\
\hline $62.7 \mathrm{a}-\mathrm{d}$ & $64.73 \mathrm{ab}$ & $10.47 \mathrm{ab}$ & $9.26 \mathrm{bc}$ & $25.4 \mathrm{e}-\mathrm{j}$ & $22.9 \mathrm{~g}-\mathrm{i}$ & $\mathrm{OM}_{1}$ & $\mathrm{AS}_{1}$ & $\mathrm{Fe}_{2}$ \\
\hline $55.5 \mathrm{~b}-\mathrm{e}$ & $.18 \mathrm{bc}$ & 11.1 & $9.83 \mathrm{a}-\mathrm{c}$ & $21.1 \mathrm{~g}-\mathrm{k}$ & $17.7 \mathrm{~h}-\mathrm{j}$ & $\mathrm{OM}_{2}$ & $\mathrm{AS}_{1}$ & $\mathrm{Fe}_{2}$ \\
\hline $61 \mathrm{a}-\mathrm{d}$ & $a-c$ & 10.1 & $11.38 \mathrm{ab}$ & $26.4 \mathrm{e}-\mathrm{j}$ & $24.7 \mathrm{e}-\mathrm{i}$ & $\mathrm{OM}_{3}$ & $\mathrm{AS}_{1}$ & $\mathrm{Fe}_{2}$ \\
\hline $62.5 \mathrm{a}-\mathrm{d}$ & 60.9 & 10.6 & $a b$ & $25.2 \mathrm{e}-\mathrm{j}$ & $21.2 \mathrm{~h}-\mathrm{j}$ & $\mathrm{OM}_{1}$ & $\mathrm{AS}_{2}$ & $\mathrm{Fe}_{2}$ \\
\hline 60.8 a-e & $60.43 \mathrm{a}-\mathrm{c}$ & $11.11 \mathrm{ab}$ & $7 \mathrm{bc}$ & $48.5 \mathrm{~b}-\mathrm{d}$ & $43 \mathrm{~b}-\mathrm{d}$ & $\mathrm{OM}_{2}$ & $\mathrm{AS}_{2}$ & $\mathrm{Fe}_{2}$ \\
\hline $65.5 \mathrm{a}-\mathrm{c}$ & $68.48 \mathrm{a}$ & $12.16 \mathrm{a}$ & $10.14 \mathrm{a}-\mathrm{c}$ & $48.8 \mathrm{~b}-\mathrm{d}$ & $40.8 \mathrm{~b}-\mathrm{d}$ & $\mathrm{OM}_{3}$ & $\mathrm{AS}_{2}$ & $\mathrm{Fe}_{2}$ \\
\hline $63.1 \mathrm{a}-\mathrm{d}$ & $55.68 \mathrm{a}-\mathrm{c}$ & $11.57 \mathrm{ab}$ & $9.95 \mathrm{a}-\mathrm{c}$ & $28.5 \mathrm{e}-\mathrm{j}$ & 29.7 d-h & $\mathrm{OM}_{1}$ & $\mathrm{AS}_{3}$ & $\mathrm{Fe}_{2}$ \\
\hline $65.8 \mathrm{a}-\mathrm{c}$ & $52.03 \mathrm{a}-\mathrm{c}$ & $10.37 \mathrm{ab}$ & $10.49 \mathrm{a}-\mathrm{c}$ & $42.7 \mathrm{c}-\mathrm{e}$ & $38.3 \mathrm{~b}-\mathrm{e}$ & $\mathrm{OM}_{2}$ & $\mathrm{AS}_{3}$ & $\mathrm{Fe}_{2}$ \\
\hline $62.9 \mathrm{a}-\mathrm{d}$ & $66.93 \mathrm{a}$ & $11.52 \mathrm{ab}$ & $10.75 \mathrm{a}-\mathrm{c}$ & $58 \mathrm{ac}$ & $50.9 \mathrm{~b}$ & $\mathrm{OM}_{3}$ & $\mathrm{AS}_{3}$ & $\mathrm{Fe}_{2}$ \\
\hline 60.7 a-e & $57.03 \mathrm{a}-\mathrm{c}$ & & $31 \mathrm{a}-\mathrm{c}$ & $33 \mathrm{~d}-\mathrm{g}$ & $29.3 \mathrm{~d}-\mathrm{h}$ & $\mathrm{OM}_{1}$ & $\mathrm{AS}_{1}$ & $\mathrm{Fe}_{3}$ \\
\hline $64.5 \mathrm{a}-\mathrm{d}$ & $55.23 \mathrm{a}-\mathrm{c}$ & $11.64 \mathrm{ab}$ & $10.42 \mathrm{a}-\mathrm{c}$ & $39.3 \mathrm{~d}-\mathrm{f}$ & $35 \mathrm{c}-\mathrm{g}$ & $\mathrm{OM}_{2}$ & $\mathrm{AS}_{1}$ & $\mathrm{Fe}_{3}$ \\
\hline $58.6 \mathrm{a}-\mathrm{e}$ & $56.58 \mathrm{a}-\mathrm{c}$ & $10.25 \mathrm{ab}$ & $10.57 \mathrm{a}-\mathrm{c}$ & $39.8 \mathrm{~d}-\mathrm{f}$ & $37.1 \mathrm{c}-\mathrm{f}$ & $\mathrm{OM}_{3}$ & $\mathrm{AS}_{1}$ & $\mathrm{Fe}_{3}$ \\
\hline $62.3 \mathrm{a}-\mathrm{d}$ & & & & $27 \mathrm{ej}$ & $23.9 \mathrm{f}-\mathrm{i}$ & $\mathrm{OM}_{1}$ & $\mathrm{AS}_{2}$ & $\mathrm{Fe}_{3}$ \\
\hline $61.6 \mathrm{a}-\mathrm{d}$ & & & 5 a-c & $57 \mathrm{ac}$ & $48.1 \mathrm{bc}$ & $\mathrm{OM}_{2}$ & $\mathrm{AS}_{2}$ & $\mathrm{Fe}_{3}$ \\
\hline $63.4 \mathrm{a}-\mathrm{d}$ & & $1077 \mathrm{ah}$ & & $71.8 \mathrm{a}$ & $64.3 \mathrm{a}$ & $\mathrm{OM}_{3}$ & $\mathrm{AS}_{2}$ & $\mathrm{Fe}_{3}$ \\
\hline $61.9 \mathrm{a}-\mathrm{d}$ & $.63 \mathrm{c}$ & & $12.45 \mathrm{a}$ & $22.3 \mathrm{f}-\mathrm{k}$ & $17.8 \mathrm{~g}-\mathrm{i}$ & $\mathrm{OM}_{1}$ & $\mathrm{AS}_{3}$ & $\mathrm{Fe}_{3}$ \\
\hline $68.5 \mathrm{a}$ & & & $10.95 \mathrm{ab}$ & $42.1 \mathrm{c}-\mathrm{e}$ & $34.8 \mathrm{cg}$ & $\mathrm{OM}_{2}$ & $\mathrm{AS}_{3}$ & $\mathrm{Fe}_{3}$ \\
\hline $67.5 \mathrm{ab}$ & $64.15 \mathrm{ab}$ & $11.33 \mathrm{ab}$ & $10.14 \mathrm{a}-\mathrm{c}$ & $64.1 \mathrm{ab}$ & $50.6 \mathrm{~b}$ & $\mathrm{OM}_{3}$ & $\mathrm{AS}_{3}$ & $\mathrm{Fe}_{3}$ \\
\hline $52.9 \mathrm{de}$ & $61.03 \mathrm{a}-\mathrm{c}$ & $10.16 \mathrm{ab}$ & $9.69 \mathrm{bc}$ & $14.4 \mathrm{~h}-\mathrm{k}$ & $16.9 \mathrm{~g}-\mathrm{i}$ & $(\mathrm{Fe}$ & Chel & ate) \\
\hline
\end{tabular}

* values followed by same letters do not differ significantly at $0.05 \%$ significant level $\mathrm{Fe}_{1}, \mathrm{Fe}_{2}$ and $\mathrm{Fe}_{3}$, respectively, 0,1 and $2 \mathrm{~kg}$ of ferrous sulfate, $\mathrm{AC}_{1}, \mathrm{AC}_{2}$ and $\mathrm{AC}_{3}$, respectively, 0, 5/0, and 1 $\mathrm{L}$ of sulfuric acid and $\mathrm{OM}_{1}, \mathrm{OM}_{2}$ and $\mathrm{OM}_{3}$, respectively, 0,2 and $4 \mathrm{~kg}$ organic matter per tree. 


\section{Fruit sugar/acid ratio}

The treatments did not significantly affect fruit sugar/acid ratio in the two years the experiment was conducted (Tables 2, 3). However, the highest fruit sugar/ acid ratio in the first year was that of the treatment $\mathrm{Fe}_{3} \mathrm{AC}_{3} \mathrm{OM}_{1}$ and that of $\mathrm{Fe}_{2} \mathrm{AC}_{2} \mathrm{OM}_{3}$ in the second year, which were 9.07 and 10.4 percent higher compared to the control treatment. The noteworthy point in the effects of the treatments on fruit sugar/acid ratios was the inverse effects of organic matter application in the first year that reduced fruit sugar content and increased fruit acid content in most treatments in which organic matter was applied.

Such results were obtained in a research that was conducted on kiwi and apple trees in which organic methods were compared with customary ones, and the reason for obtaining these results can be the increased access to nitrogen that increases fruit acid and reduces fruit sugar (Pecket et al., 2006). The sugar/acid ratio in the treatment of applying iron chelate decreased compared to the control and the $\mathrm{Fe}_{3} \mathrm{AC}_{3} \mathrm{OM}_{1}$ treatment (Table 5). Different levels of iron sulfate together with sulfuric acid application did not very significantly affect the sugar/acid ratio, but increased ratio of sugar/ acid ration was observed in our experiment too because the treatments corrected iron deficiency and chlorosis in kiwi trees. This increase in the sugar/ acid ratio is one of the most important qualitative factors in marketing the crop.

\section{Vitamin C}

Kiwi fruit is naturally rich in vitamin $\mathrm{C}$. This raises the health benefits (because vitamin $\mathrm{C}$ is an antioxidant) and nutritional value of this fruit. Kiwi fruits usually contain 25-155 milligrams of vitamin C per 100 grams of fresh fruit (White et al., 2005).Various factors such as kiwi variety, local environmental conditions, and especially tree nutrition, affect nutritious compounds, including vitamin $\mathrm{C}$, found in kiwi fruit. Only the individual effects of organic matter on fruit vitamin $\mathrm{C}$ content was significant at the $5 \%$ probability level in our experiment. The interactions of the treatments did not have any significant effects in the first year, but in the second year significant differences were observed at the $5 \%$ probability level after the treatments were performed. The highest fruit vitamin $\mathrm{C}$ content in the first year was that of the $\mathrm{Fe}_{2} \mathrm{AC}_{2} \mathrm{OM}_{3}$ treatment and in the second year that of $\mathrm{Fe}_{3} \mathrm{AC}_{3} \mathrm{OM}_{2}$, which were 20.95 and 23.2 percent higher than fruit vitamin $\mathrm{C}$ in the control treatment, respectively (Table 5). Application of iron chelate did not show any significant differences in vitamin $\mathrm{C}$ content compared to the other treatments in the first year, but in the second year these differences became significant so that in the best treatment $\left(\mathrm{Fe}_{3} \mathrm{AC}_{3} \mathrm{OM}_{2}\right)$ the vitamin $\mathrm{C}$ content was 22.8 higher than of the iron chelate treatment (Table 5). Kiwi fruit has greater antioxidant activity and higher vitamin $\mathrm{C}$, polyphenol, and mineral matter contents in the organic method compared to the customary method, in which chemicals are used (Amodio et al., 2007). Comparison of the nutritional value and antioxidant contents of kiwi fruit in the organic agriculture method (in which manure replaces chemical fertilizers) and the integrated and the customary methods indicated that the vitamin $\mathrm{C}$ content in the organic method was significantly higher (Ashoorinezhad et al., 2011). Use of organic methods in tangerine fruit production also increased vitamin $\mathrm{C}$, mineral matter, and carotenoids contents compared to chemical treatments (Beltran et al., 2008). Application of organic matter together with iron fertilizer and acid in our experiment prepared suitable 
conditions for kiwi trees to overcome chlorosis and, hence, increased photosynthetic capability of the trees and the raised the level of photosynthetates production including sugars, which increased vitamin $\mathrm{C}$ synthesis.

\section{General Conclusions}

In our experiment, we tackled the problem of chlorosis in kiwi orchards in a region in the central part of Mazandaran Province by injecting a combination of iron sulfate, sulfuric acid, and organic matter with a Biolift machine into the soil around kiwi trees. Iron sulfate provided the required iron element, sulfuric acid reduced $\mathrm{pH}$ locally and increased iron absorption, and organic matter raised the efficiency and the ability to absorb iron sulfate. This method is an effective and useful strategy and can replace that of deep placement of iron chelates which entails high costs, has short- time effectiveness, and is accompanied by environmental problems too. Based on obtained results of our experiment, injecting one kilogram of iron sulfate, half a liter of sulfuric acid, and four kilograms of organic matter increased iron availability for kiwi trees and, hence, increased leaf chlorophyll concentration, solved the problem of iron chlorosis, and increased photosynthetic capability and efficiency. As a result, many of the qualitative and quantitative characters of kiwi trees (including yield, vitamin $\mathrm{C}$ content, and sugar/acid ratio) were affected for a period of at least two tears.

\section{REFERENCES}

[1] Akbari, M., Zare, M. J., Mehrabi, A. A., Nasrollahnezhad, A. A. (2013): Investigation of the effect of phosphorus fertilizer and spraying Fe chellat micronutrients absorption rate of proline and soluble carbohydrates in bread wheat and some of its ancestral species in dry land condition. - Production Electronic Journal of Crop 6(1): 1-17.

[2] Alvarez-Fernandez, A., Paniagua, P., Abadia, J., Abadia, A. (2003): Effects of Fe deficiency chlorosis on yield and fruit quality in Peach (Prunus Persica L. Batsch). - Journal of Agricultural and Food Chemistry 51: 5738-5744.

[3] Amodio, M. L., Colelli, G., Hasey, J. K., Kader, A. A. (2007): A comparative study of composition and post-harvest performance of organically and conventionally grown kiwifruits. - Journal of the Science of Food and Agriculture 87: 1228-1236.

[4] Ashournezhad, M., Ghasemnezhad, M., Aghajanzadeh, S., Bakhshi, D., Fattahi Moghaddam, M. (2012): A comparison of the nutritional value of and the antioxidant compounds present in the organic, integrated, and conventionally produced kiwifruits cv.Hayward. - Iranian Journal of Horticulture science 42(4): 413-422.

[5] Bates, L. S., Waldren, R. P., Treare, I. D. (1973): Rapid determination of free praline for water-stress studies. - Plant Soil 39: 205-207.

[6] Beltran, F. G., Perez-Lopez, A. J., Lopez-Nicola, J. M., Carbonell-Barrachina, A. (2008): Effects of agricultural practices on instrumental colour, mineral content, carotenoid composition, and sensory quality of mandarin orange juice, cv. Hernandina. - Journal of the science of food and Agriculture 88: 1731-1738.

[7] Crane, J., Schaffer, B., Li, Y., Evans, E., Montas, W., Li, C. (2007): Effect of foliarly-applied acids and ferrous sulfate on iron nutrition of avocado trees. - Proceedings VI World Avocado Congress. 
[8] Delaney, A. J., Hu, C. A. A., Kishor, K. P. B., Verma, D. P. S. (1993): Cloning ornithineaminotransferase cDNA from Vigna anaconitiofolia by trans-complementation in Escherichia coli and regulation of proline biosynthesis. - Journal of Biological Chemistry 268: 1867318678.

[9] Fathi Amirkhiz, K., Amini Dehaghi, M., Modarres Sanavi, S. A. M., Heshmati, S. (2011): The effects of soil and foliar application of $\mathrm{Fe}$ on some biochemical characteristics of safflower (Carthamus tinctorius L.) under two irrigation regimes. - Iranian Journal of Crop Sciences 42(3): 509-518.

[10] Faust, M. (1989): Physiology of Temperate Zone Fruit Trees. - John Wiley \& Sons Incorporation, New York. 605 pp.

[11] Havlin, J., Beaton, J. D., Tisdale, S. L., Nelson, W. L. (2005): Soil fertility and fertilizers, $7^{\text {th }}$ edition. - Pearson Prentice Hall.

[12] Iglesias, I., Dalmau, R., Marce, X., Delcampillo, M. C., Barron, V., Torrent, J. (2003): Fertilization with iron (II)-phosphate effectively prevents iron clorosis in pear trees pyrus commonis. - Ishs Acta Horticulture 511: 65-72.

[13] Kalbasi, M. (1986): Local acidification of soil as a mean to alleviation iron chlorosis in quince orchards. - Journal Plant Nutrition 9: 1001-1010.

[14] Karlsons, A., Osvalde, A., Levinsh, G. (2011): Growth and mineral nutrition of two Triglocin species from saline wetlands: adaptation strategies to conditions of heterogeneous mineral supply. - Environmental and Experimental Biology 9: 83-90.

[15] Labanauskas, C. K., Handy, M. F. (1970): The effect of iron and manganese deficiencies on accumulation of non-protein and protein amino acids in macadamia leaves. - Journal of the American Society of Horticultural science 95: 218-223.

[16] Peck, G. M., Andrew, P., Reganold, J., Fellman, J. (2006): Apple orchard productivity and fruit quality under organic, conventional, and integrated management. - Hortscience 41(1): 99-107.

[17] Pestana, M., Varennes, A., Faria, E. A. (2003): Diagnosis and correction of iron chlorosis in fruit trees. - Food, Agriculture and Environment (1): 46-51.

[18] Possingham, J. V. (1956): The effect of mineral nutrition on the content of free amino acids and amides in tomato plants. - Australian Journal of Biological Science 9(4): 539-551.

[19] Rabe, E. (1990): Stress physiology: the functional significance of the accumulation of nitrogen-containing compounds. - Journal Horticulture science 65(3): 231-243.

[20] Rambola, A., Tagliavini, M. (2006): Iron nutrition of fruit tree crops. - In: Barton, L. L., Abad, J. (eds.) Iron nutrition in plants and rhizospheric microorganisms. Springer, Dordrecht, the Netherlands. 23-59

[21] Rodríguez-Celma, J., Lin, W. D., Fu, G. M., Abadia, J., Lopez-Millan, A. F., Schmidt, W. (2013): Mutually exclusive alterations in secondary metabolism are critical for the uptake of insoluble iron compounds by Arabidopsis and Medicago truncatula. - Plant Physiology 162: $1473-1485$.

[22] Rombola, A. D., Bruggemann, W., Lopez Millan, A. F., Tagliavini, M., Abadia, J., Marangoni, B., Moog, P. R. (2002): Biochemical responses to iron deficiency in kiwifruit (Actinidia deliciosa). - Tree Physiology 22: 869-875.

[23] Rombola, A. D., Toselli, M., Carpintero, J., Ammari, T., Quartieri, M., Torrent, J., Marangoni, B. (2003): Prevention of iron-deficiency induced chlorosis in Kiwifruit (Actinidia deliciosa) through soil application of synthetic Vivianite in a calcareous soil. Journal of Plant Nutrition 26(10/11): 2031-2041.

[24] Schmidt, H., Günther, C., Weber, M., Spörlein, C., Loscher, S., Böttcher, C., Schobert, R., Clemens, S. (2014): Metabolome analysis of Arabidopsis thaliana roots identifies a key metabolic pathway for iron acquisition. - PloS ONE 9, e102444. 
[25] Sisó-Terraza, P., Rios, J. J., Abadía, J., Abadía, A., Álvarez-Fernández, A. (2016): Flavins secreted by roots of iron-deficient Beta vulgaris enable mining of ferric oxide via reductive mechanisms. - New Phytologist 209: 733-745.

[26] Vigani, G., Zocchi, G., Bashir, K., Philippar, K., Briat, J. F. (2013): Cellular iron homeostasis and metabolism in plant. - Frontiers in Plant Science 4: 490.

[27] White, A., Nihal de Silva, H., Requejo-Tapia, C., Harker, F. R. (2005): Evaluation of softening characteristics of fruit from 14 species of Actinidia. - Post-harvest Biology and Technology 35: 143-151. 